DOI 10.22460/jpmi.v1i3.355-360

\title{
PENGARUH PEMBELAJARAN BERBASIS MASALAH TERHADAP KEMAMPUAN PEMECAHAN MASALAH MATEMATIS SISWA SMA
}

\author{
Ibnu Imam Al Ayubi ${ }^{1}$, Erwanudin ${ }^{2}$, Martin Bernard ${ }^{3}$ \\ 1,2,3 IKIP Siliwangi, Jl. Terusan Jenderal Sudirman, Cimahi, Jawa Barat, Indonesia \\ ${ }^{1}$ hayugan_31@yahoo.com, ${ }^{2}$ nudinerwan09@gmail.com, ${ }^{3}$ pamartin23rnard@gmail.com
}

Diterima: 10 Maret 2018; Disetujui: 28 Mei 2018

\begin{abstract}
This research is motivated by the low ability of mathematical problem solving of high school students who need a learning approach to overcome the problem. Alternative approach used is problem-based learning approach. This study aims to examine whether the problem-solving ability of mathematical students using problem-based learning is better than using ordinary learning. The research method used is experimental method. At the end of the learning the two classes were given a test. The population in this study were high school students in SMAN 2 Cimalaka class XI, while the sample consisted of two classes chosen at random. The data collection in this research is a test of five questions, then the scores of mathematical problem solving abilities are analyzed by descriptive statistics and inferential statistic using two difference test average. Based on the results of research, both from data analysis and hypothesis testing, the authors conclude that the problem solving ability of mathematical students using problem-based learning is better than using ordinary learning.
\end{abstract}

Keywords: Mathematical Problem Solving Ability, Problem Based Learning

\begin{abstract}
Abstrak
Penelitian ini dilatarbelakangi oleh rendahnya kemampuan pemecahan masalah matematis siswa Sekolah Menengah Atas yang diperlukan pendekatan pembelajaran untuk mengatasi masalah tersebut. Alternatif pendekatan yang digunakan adalah pendekatan pembelajaran berbasis masalah. Penelitian ini bertujuan untuk menelaah apakah kemampuan pemecahan masalah matematis siswa yang menggunakan pembelajaran berbasis masalah lebih baik daripada yang menggunakan pembelajaran biasa. Metode penelitian yang digunakan adalah metode eksperimen. Pada akhir pembelajaran kedua kelas diberi tes. Populasi dalam penelitian ini adalah siswa SMA di SMAN 2 Cimalaka kelas XI, sedangkan sampelnya terdiri dari dua kelas yang dipilih secara acak. Pengumpulan data dalam penelitian ini berupa tes sebanyak lima soal uraian, kemudian data skor kemampuan pemecahan masalah matematis tersebut dianalisis dengan statistik deskriptif dan statistik inferensial dengan menggunakan uji perbedaan dua rata-rata. Berdasarkan hasil penelitian, baik dari analisis data maupun pengujian hipotesis, maka penulis menyimpulkan bahwa kemampuan pemecahan masalah matematis siswa yang menggunakan pembelajaran berbasis masalah lebih baik daripada yang menggunakan pembelajaran biasa.
\end{abstract}

Kata Kunci: Kemampuan Pemecahan Masalah Matematis, Pembelajaran Berbasis Masalah

How to cite: Al Ayubi, I. I,, Erwanudin, E., \& Bernard, M. (2018). Pengaruh Pembelajaran Berbasis Masalah Terhadap Kemampuan Pemecahan Masalah Matematis Siswa SMA. JPMI - Jurnal Pembelajaran Matematika Inovatif, 1 (3), 355-360. 


\section{PENDAHULUAN}

Matematika akan terus dipelajari secara berkesinambungan sampai jenjang pendidikan yang paling tinggi sekalipun. Hal ini didukung oleh pendapat Ruseffendi (2006) yang mengatakan bahwa matematika adalah ratunya ilmu (Mathematics is the Queen of the Sciences) yang tidak bergantung pada bidang studi lain. Menurut Bernard (2015) bahwa mata pelajaran Matematika perlu diberikan kepada semua peserta didik mulai dari sekolah dasar sampai sekolah menengah harus dibekalii dengan kemampuan berpikir logis, analitis, sistematis, kritis, dan kreatif, serta kemampuan bekerjasama. Pada saat peneliti melaksanakan PLP (Praktek Latihan Profesi), tidak sedikit siswa yang berasumsi bahwa matematika merupakan mata pelajaran yang sulit. Hal ini dikarenakan matematika merupakan pelajaran abstrak yang membutuhkan pemikiran yang kompleks. Untuk beberapa materi, matematika disajikan dalam soal cerita yang berorientasi pada kehidupan nyata. Hal ini bertujuan agar materi matematika lebih mudah dipahami. Siswa dituntut untuk dapat menyelesaikan soal matematika yang berorientasi pada kehidupan nyata. Kemampuan pemecahan masalah adalah kemampuan yang digunakan ketika menyelesaikan soal matematika tersebut. Hal ini diperkuat dengan pendapat Dewey (Rusmono, 2014) yang mengatakan bahwa sekolah merupakan laboratorium untuk pemecahan masalah kehidupan nyata, karena setiap siswa memiliki kebutuhan untuk menyelidiki lingkungan dan membangun pengetahuannya secara pribadi.

Namun, pada kenyataannya kemampuan pemecahan masalah matematis siswa masih rendah (Hidayat \& Sariningsih, 2018; Wahyu, 2014). Hal ini dapat dilihat dari hasil Trends in International Mathematics and Science Study (TIMSS). Berdasarkan keikutsertaan Indonesia di TIMSS diperoleh data sebagai berikut:

Tabel 1. Data Hasil TIMSS Indonesia

\begin{tabular}{cccc}
\hline Tahun & Nilai Rata-rata & Peringkat & $\begin{array}{c}\text { Jumlah } \\
\text { Peserta }\end{array}$ \\
\hline 1999 & 403 & 34 & 38 \\
2003 & 411 & 35 & 46 \\
2007 & 397 & 36 & 49 \\
2011 & 386 & 38 & 42 \\
\hline
\end{tabular}

Nilai standar rata-rata yang ditetapkan oleh TIMSS adalah 500. Dalam empat kali keikutsertaan, Indonesia memperoleh nilai di bawah rata-rata yang telah ditetapkan. Berdasarkan fakta yang telah ditemukan, kemampuan pemecahan masalah matematis siswa masih rendah. Oleh karena itu, salah satu upaya guru untuk meningkatkan kemampuan pemecahan masalah matematis siswa adalah dengan melakukan pendekatan pembelajaran yang sesuai dan berkaitan dengan pemecahan masalah.

Berkenaan dengan kemampuan pemecahan masalah matematis siswa yang digunakan ketika menyelesaikan soal-soal yang berorientasi pada kehidupan nyata, maka salah satu pendekatan pembelajaran yang sesuai untuk meningkatkan kemampuan pemecahan masalah matematis siswa adalah pendekatan pembelajaran berbasis masalah atau pendekatan Problem Based Learning. Menurut Hanafiah \& Suhana (2009), Problem Based Learning adalah pendekatan yang menggunakan masalah nyata sebagai konteks sehingga siswa dapat belajar berpikir kritis dalam melakukan pemecahan masalah yang bertujuan untuk memperoleh pengetahuan atau konsep yang esensial dari materi yang diajarkan. Menurut Dewey (Amir, 2010), pengetahuan yang dipelajari siswa seharusnya bukan informasi yang banyak terdapat di buku pelajaran, 
tetapi pengetahuan menjadi berguna (useful) dan hidup (alive) ketika diterapkan dan dikembangkan sebagai solusi untuk beberapa masalah.

Berdasarkan latar belakang masalah di atas, maka permasalahan dalam penelitian ini dirumuskan, sebagai berikut: Apakah kemampuan pemecahan masalah matematis siswa yang menggunakan pembelajaran berbasis masalah lebih baik daripada yang menggunakan pembelajaran biasa? Sesuai dengan rumusan masalah di atas, maka tujuan penelitian ini adalah untuk menelaah apakah kemampuan pemecahan masalah matematis siswa yang menggunakan pembelajaran berbasis masalah lebih baik daripada yang menggunakan pembelajaran biasa

\section{METODE}

Metode yang digunakan dalam penelitian ini adalah metode eksperimen. Metode eksperimen adalah metode yang penelitiannya berkenaan dengan sebab akibat dengan pemilihan sampel secara acak. Terdapat dua kelompok dalam penelitian ini, yaitu kelompok eksperimen (kelas eksperimen) dan kelompok kontrol (kelas kontrol). Kelompok eksperimen menggunakan pembelajaran berbasis masalah sedangkan kelompok kontrol menggunakan pembelajaran biasa. Pembelajaran berbasis masalah dan pembelajaran biasa ditetapkan sebagai variabel bebas, sedangkan kemampuan pemecahan masalah matematis siswa ditetapkan sebagai variabel terikat.

Desain yang digunakan dalam penelitian ini adalah kelompok kontrol hanya postes, yaitu suatu bentuk desain penelitian dalam metode eksperimen. Berikut disajikan desain penelitiannya.
A $\quad X \quad O \quad$ Ruseffendi (2010)
A
$\mathrm{O}$

Keterangan:

A : Pengambilan sampel secara acak

$\mathrm{X} \quad$ : Perlakuan pembelajaran berbasis masalah

$\mathrm{O} \quad$ : Postes (tes kemampuan pemecahan masalah matematis)

Populasi dalam penelitian ini adalah seluruh siswa SMA di SMAN 2 Cimalaka. Sekolah tersebut terdiri dari kelas-kelas yang heterogen dan tidak ada kelas unggulan. Sampel dalam penelitian ini adalah dua kelas yang ada di SMA tersebut. Pengambilan sampel dipilih secara acak dengan teknik cluster sampling. Dari empat kelas dipilih dua kelas yang dijadikan sebagai kelas penelitian dengan syarat kedua kelas merupakan sampel yang setara

\section{HASIL DAN PEMBAHASAN}

\section{Hasil}

Penelitian dilaksanakan selama satu bulan dengan jadwal yang fluktuatif, dimana terpartisi oleh hari libur nasional dan adanya acara-acara sekolah yang melibatkan seluruh siswa/i-nya. Sebelum melaksanakan pembelajaran, peneliti berkonsultasi kepada guru mata pelajaran dengan tujuan mengetahui karakteristik awal siswa dan meminta nilai pada materi 
sebelumnya. Nilai tersebut dipakai untuk mengetahui kesetaraan kedua kelas yang digunakan untuk penelitian. Setelah pembelajaran selesai, peneliti melaksanakan postes di kedua kelas untuk mengetahui hasil akhir setelah dilakukan pembelajaran yang berbeda. Data statistik nilai awal dan postes disajikan dalam Tabel 2 sebagai berikut:

Tabel 2. Data Statistik Hasil Penelitian

\begin{tabular}{|l|l|l|l|l|l|l|l|l|}
\hline \multirow{2}{*}{ Kelas } & \multicolumn{4}{|l|}{ Nilai awal } & \multicolumn{2}{l|}{ Postes } \\
\cline { 2 - 9 } & $\mathrm{N}$ & $\bar{X}$ & StDev & SMI & $\mathrm{N}$ & $\bar{X}$ & StDev & SMI \\
\hline Eksperimen & 26 & 69,42 & 10,89 & 100 & 26 & 8,962 & 1,886 & 12 \\
\hline Kontrol & 26 & 68,65 & 10,06 & 100 & 26 & 7,846 & 2,327 & 12 \\
\hline
\end{tabular}

Analisis data postes dilakukan untuk mengetahui apakah kemampuan pemecahan masalah matematis siswa yang menggunakan pembelajaran berbasis masalah lebih baik daripada yang menggunakan pembelajaran biasa. Berikut ini disajikan pada Tabel 3 hasil uji perbedaan dua rata-rata data postes.

Tabel 3. Uji Perbedaan Dua Rata-Rata Data Postes

\begin{tabular}{lc}
\hline \multicolumn{1}{c}{ Kelas } & $\boldsymbol{P}$-value \\
\hline Eksperimen & \\
Kontrol & 0,03 \\
\hline
\end{tabular}

Berdasarkan data yang diperoleh dari hasil penelitian, kesimpulan dari hipotesis yang dapat diambil adalah: Kemampuan pemecahan masalah matematis siswa yang menggunakan pembelajaran berbasis masalah lebih baik daripada yang menggunakan pembelajaran biasa.

\section{Pembahasan}

Berdasarkan hasil analisis data, dapat diambil kesimpulan bahwa Tidak terdapat perbedaan kemampuan awal pemecahan masalah matematis siswa yang menggunakan pembelajaran berbasis masalah dengan yang menggunakan pembelajaran biasa. Ini berarti bahwa kedua sampel yang dijadikan sebagai kelas penelitian adalah setara. Setelah diperoleh hasil analisis data nilai awal dari kedua kelas, selanjutnya peneliti melaksanakan pembelajaran. Kelas eksperimen menggunakan pembelajaran berbasis masalah. Pembelajaran berbasis masalah menjadikan masalah sebagai bahan dalam pembelajaran. Pembelajaran berbasis masalah dilakukan secara berkelompok. Ini bertujuan agar siswa aktif berpartisipasi dalam kelompok, mengingat tanggung jawab dalam memecahkan masalah bertumpu pada siswa, sedangkan peran guru hanya sebagai fasilitator dalam membimbing proses pembelajaran. Setiap kelompok terdiri dari 4-5 siswa yang memiliki kemampuan yang heterogen.

Dalam proses pembelajaran, masing-masing kelompok diberikan LKS. Tujuannya adalah agar siswa lebih terarah dalam menyelesaikan soal pemecahan masalah melalui tahapan pembelajaran berbasis masalah, yaitu mengorganisasikan siswa kepada masalah, 
mengorganisasikan siswa untuk belajar, membantu penyelidikan mandiri dan kelompok, mengembangkan dan mempresentasikan hasil karya, serta menganalisis dan mengevaluasi proses pemecahan masalah. Pembelajaran berbasis masalah dapat memotivasi siswa dengan menimbulkan rasa ingin tahunya, dengan begitu siswa dapat menambah pengetahuan dan pengalaman baru dengan menemukan solusi dari pemecahan masalah tersebut. Pengetahuan baru yang diperoleh melalui presentasi dari beberapa kelompok mengenai hasil diskusinya.

Lain halnya dengan kelas kontrol yang menggunakan pembelajaran biasa. Sekolah tersebut mengacu pada Kurikulum 2013, sehingga pembelajaran yang biasa dilakukan adalah pembelajaran dengan pendekatan scientific. Pembelajaran dengan pendekatan scientific juga dilakukan secara berkelompok. Namun terdapat perbedaan, karena pendekatan scientific lebih menonjolkan pengamatan dan penemuan suatu konsep matematika yang berbasis objek yang nyata. Adapun langkah-langkah pembelajaran dengan pendekatan scientific adalah mengamati, menanya, menalar, mencoba, dan membentuk jejaring. Pendekatan scientific juga menggunakan LKS sebagai pemicu agar siswa aktif selama proses pembelajaran. Namun yang membedakan adalah tahap-tahap pengerjaan soal pemecahan masalahnya. Kelas eksperimen yang menggunakan pembelajaran berbasis masalah diawali dengan masalah, sedangkan kelas kontrol yang menggunakan pembelajaran biasa diawali dengan ringkasan materi dan latihan soal. Setelah pembelajaran pada kedua kelas selesai, kemudian dilaksanakan tes akhir (postes). Berdasarkan analisis data postes, dapat diambil kesimpulan sesuai dengan hipotesis bahwa Kemampuan pemecahan masalah matematis siswa yang menggunakan pembelajaran berbasis masalah lebih baik daripada yang menggunakan pembelajaran biasa.

\section{KESIMPULAN}

Berdasarkan hasil penelitian yang didasarkan pada uji normalitas, uji homogenitas dan uji perbedaan dua rata-rata data postes pada kelas eksperimen yang menggunakan pembelajaran berbasis masalah dan kelas kontrol yang menggunakan pembelajaran biasa, dapat disimpulkan bahwa kemampuan pemecahan masalah matematis siswa yang menggunakan pembelajaran berbasis masalah lebih baik daripada yang menggunakan pembelajaran biasa.

\section{DAFTAR PUSTAKA}

Amir, T. (2010). Inovasi Pendidikan melalui Problem Based Learning. Jakarta: Kencana Prenada Media Group.

Bernard, M. (2015). Meningkatkan kemampuan komunikasi dan penalaran serta disposisi matematik siswa SMK dengan pendekatan kontekstual melalui game adobe flash cs 4.0. Infinity Journal, 4(2), 197-222.

Hanafiah, N dan Suhana, C. (2009). Konsep Strategi Pembelajaran. Bandung: Refika Aditama.

Hidayat, W., \& Sariningsih, R. (2018). Kemampuan Pemecahan Masalah Matematis dan Adversity Quotient Siswa SMP Melalui Pembelajaran Open Ended. JNPM (Jurnal Nasional Pendidikan Matematika), 2(1), 109-118.

Ruseffendi, E. T. (2006). Pengantar kepada Membantu Guru Mengembangkan Kompetensinya dalam Pengajaran Matematika untuk Meningkatkan CBSA. Bandung: Tarsito. 
360 Al Ayubi, Erwanudin, \& Bernard, Pengaruh Pembelajaran Berbasis Masalah ...

Ruseffendi, E. T. (2010). Dasar-Dasar Penelitian Pendidikan dan Bidang Non Eksakta Lainnya. Bandung: Tarsito.

Rusmono. (2014). Strategi Pembelajaran dengan Problem Based Learning itu Perlu Untuk Meningkatkan Profesionalitas Guru, Cet. 2. Bogor: Ghalia Indonesia.

Wahyu, H. (2014). The Implementation of MEAs Instruction to Students' Mathematics Problem Solving and Connecting Ability. In Proceeding of International Conference on Research, Implementation and Education of Mathematics and Sciences 2014. Yogyakarta State University. 